\title{
A Critical View on the Teaching of Culture in the Foreign Language Classroom
}

\author{
Danilo Neves Pereira \\ Emory University, Atlanta, United States of America
}

\begin{abstract}
This paper is a theoretical article that aims to present some concepts related to the term "culture" that can help language teachers understand critically the intercultural processes that take place during the teaching and learning of a foreign language. Using some of the most important writers in Applied Linguistics and Critical Applied Linguistics that focus on this topic, this article discusses some definitions of the word "culture" as well as other relevant terms such as the concept of languaculture and the concept of third places. That said, this paper tries, through a theoretical discussion, to draw attention to the importance of culture based on an approach that is in consonance with Critical Applied Linguistics.
\end{abstract}

Keywords: culture, languaculture, interculturality, language teaching

\section{Introduction}

As a teacher of English as a Foreign Language (EFL) and as an Applied Linguist living and working in a communicative approach era, it is hard not to notice that the word culture seems to be everywhere, permeating almost every discourse that is reproduced regarding the teaching and the learning of a foreign language. From the course books we use in our classes that, not rarely, bring a set of "curiosities" about the countries that speak the target language to the very need of bringing authentic materials to the classroom, the necessity of teaching foreign cultures permeates our daily praxis. Thus, culture has recently come to play an important part in the teaching and the learning of foreign languages, mostly because of Applied Linguistics and its studies on interculturality. However, all this talk about culture raises the question as to what is culture, and, most importantly, how it should be taught in a communicative class. This article aims to answer these questions showing many different theoretical concepts and studies that focused on culture while discussing what we, teachers, can take from all these theories to apply in our own classrooms.

That said, this paper will present a brief historical background on how the word culture has been defined in anthropological studies over the years (Bauman, 1973), then it will discuss the first studies on the relationship between language and culture, more precisely, the studies by Sapir and Whorf, followed by the presentation of contemporary studies in the field of Applied Linguistics as discussed by Risager (2005). Then, to conclude this paper, we will partake in a brief discussion of post-modern critical views on the teaching of culture alongside the concepts of critical interculturality (Pennycook, 1998; Pennycook, 2001; Kubota, 2010; Tubino, 2004) and the concept of third places (Kramsch, 1993).

Danilo Neves Pereira, teaching assistant, Department of Spanish and Portuguese, Emory University, Atlanta, USA; master, Applied Linguistics, Universidade Federal de Goiás, Brazil. 


\section{What Is Culture?}

To start a discussion on what is culture in the foreign language classroom, we must do so by warning our readers that the word culture does not have only one meaning. As a matter of fact, Spencer-Oatey (2009) mentions a study carried out by Alfred Kroeber and Clyde Kluckhohn in 1952 in which they list more than 164 commonly-used definitions given to the word culture. Needless to say, each area of study defines the term according to their own necessities, at times creating their own new definitions for the word, at others, appropriating of pre-established definitions.

All this variety makes defining the term culture a very complex job for any researcher to undertake. Bauman, however, (2002) attempts to define it by exploring three commonly everyday used definitions. According to Bauman (2002), historically speaking, the word culture has been used in three different contexts, which implies in the word having three distinct meanings:

- A hierarchical meaning;

- A differential meaning;

- And a generic meaning.

Because the word culture is often times used to determine which corpus of knowledge is considered important in one's education; the first meaning ascribed to the word culture, according to Bauman (2002) is a hierarchical meaning. Based on the author, this meaning of the word culture is very popular nowadays and can be easily perceived through certain discourses that consider one group of people "well-cultivated" as opposed to another group of people who "have no culture" or have not had "access to" it. That said, according to this definition, there are two groups of people: those who have culture and those who do not. Those who do have access to culture are the possessors of culture, being supposedly in a superior social position than those who do not. Culture, in this view, is not only a commodity to be had but also a watershed between those who can afford it and those who cannot.

The second meaning used to signify culture is a differential meaning. This idea of culture as difference was firstly used in European ethnographic studies and it traces back to the colonial periods of History. In this sense, Bauman (2002) argues that the word culture was mostly used to describe how Europeans were considered civilized whereas the peoples living in the colonies were considered exotic possessors of different cultures. That means to say that to study another culture, in this context, was to study the habits and the lifestyles of the Other, whose cultures were very different from those of the "civilized" European. Simply put, in a Eurocentric viewpoint, culture was conceived as what made Europeans different from the rest of the world.

Along time, though, this differential meaning of culture changed as studies started to acknowledge the fact that the cultures of all the other non-European groups were neither better nor worse than the colonial cultures, that they were just different. In this phase of the word culture, then, it became possible to think about culture not as a commodity, but as a group of characteristics that both characterized each cultural group and differentiated them from other communities.

Still discussing different meanings historically ascribed to the word culture, Bauman (2002) goes on talking about how the term went from expressing a set of national characteristics to encompassing all human activities. As previously discussed, it was not until Europeans started accepting the existence of other non-European cultures that the term acquired its differential character. With the recognition that different peoples around the world had different cultures, there also came the recognition that different peoples shared a 
commonality, that is, their ability to create culture and this is the essence of the generic meaning ascribed to the word culture. Culture, in this definition, is everything that distinguishes human beings from animals. Then, we can say that, according to this perspective, culture encompasses all human activities, because culture is the very element that makes us, humans, different from all the other living beings in the planet; humans have and produce culture whereas animals do not.

Another author that discusses the term culture is Risager (2006). She brings a fresh view on his definitions by listing three other categories to discuss the meanings ascribed to the term culture. According to her, on top of the three meanings established by Bauman (2002) the word culture has:

- An individual meaning;

- A collective meaning;

- An aesthetic meaning.

Based on Bauman's hierarchical definition of culture, Risager (2006) reinforces the idea that the word culture can have an elitist connotation when viewed as a commodity or a set of knowledge a person can acquire through the means of study and cultivation. This elitist view, according to her, underlies the discourse that claims that a person has culture because they have had a good educational background and it reflects an individualist meaning to the word culture according to which culture is something individuals can have.

As opposed to this individualistic view on culture, Risager (2006) also mentions a collective meaning ascribed to the term, according to which, culture is viewed as a set of aspects that characterize any specific cultural group. This view, as it is quite obvious, dialogs well with Bauman's (2006) differential meaning as both categories recognize that cultures are sometimes seen as packs of cultural traits about any given culture group. In that sense, Brazilian culture, for example, would be a set of cultural aspects that determine what it is to be Brazilian, including its scope, our knowledge about our holidays, our typical foods, our literature, and so forth. All these characteristics, in consonance with a collective view of culture, makes up what Brazilian culture is since a collective of people, in this case, Brazilians, share it as a common background.

The last definition brought by Risager (2006) discusses the aesthetic side of culture. The term culture has long been associated with the arts and it is not rare to find people who still believe that having culture is parallel to mastering a certain knowledge of literature, of famous paintings, of certain classic movies, or even, of certain songs. This is the third view discussed by Risager according to which culture equals art.

This last meaning for the term is also very elitist as we start to question ourselves what art is. In the 1960s and the 1970s, a strong movement of intellectuals in England started to question this view on art and culture; especially, the reasons why academic studies on art and culture often excluded popular culture from its scope of study. This movement gave rise to what we, nowadays, call the cultural studies (Corbett, 2003). Thanks to the cultural studies, in a critical view, this idea that culture equals art has been problematized not because culture is not art whatsoever, but because art itself has been very often only considered as such when it is produced by an elite, thus implying that the popular masses do not have a culture. ${ }^{1}$

In brief, in this part of the article, we showed how Bauman (2002) and Risager (2006) dialog with each other listing different meanings ascribed to the word culture throughout history. We saw that culture is not a fixed term; but, rather, one that depends on how speakers use it and the context it is employed to acquire its full

\footnotetext{
${ }^{1}$ For more information on the history of cultural studies, read the article below: Hall, S. (1997). The centrality of culture, notes on the cultural revolutions of our time. In K. Thompson (Ed.), Media and cultural regulation. London: Thousand Oaks, New Delhi, The Open University; SAGE publication.
} 
meaning. It is obvious that, from a sociolinguistic perspective, every word and every possible meaning produced through language depends on a context to be fully understood, but what I tried to claim here in this section that the word culture is even more so because depending on the context it is employed, it can express more than 164 meanings.

In this paper, however, we understand culture from a generic viewpoint according to which culture encompasses all human activities, straying from an elitist Eurocentric vantage point. From this perspective, everything teachers do in the foreign language class is somehow related to culture, making it impossible for any language class not to be a culture class.

\section{Culture and Language: Linguistic Relativism and Languaculture}

While adopting a generic view on culture according to which culture is everything that is produced by humans then, obviously, culture is not only expressed through language, but language, as a human practice, is culture. Following this idea then, culture and language are inseparable.

That said, one of the first studies to delve into the relationship between language and people's behavior in society were the studies by Sapir and Whorf on language and thought. Nowadays, their theories are recognized as linguistic relativism and as the Sapir-Whorf hypothesis, because both Sapir and Whorf believed that our thoughts were not only constituted by our language, but also that our languages had the power to determine our thoughts. According to Kramsch (1993):

The Sapir-Whorf hypothesis makes the claim that the structure of the language one habitually uses influences the manner in which one thinks and behaves (...). Whorf concluded that the reason why different languages can lead people to different actions is because language filters their perception and the way they categorize experience. (p. 12)

To exemplify his point of view, Whorf (1956, p. 135) mentions his personal experience while he was working at a fire insurance company. In his narrative, he tells us that he was hired by a fire insurance company to investigate the causes of the many fires that were happening in his city. After studies and research, he finally found that the reason why there were so many fires in his city was because most people were used to lighting fires near "empty" fuel tanks thinking they were not dangerous because they had the word "empty" written on them, whereas, in actual fact, they were full of inflammable gas. Thus, Whorf claims that because the word "empty" in English brings up the idea of nothingness, people were inclined to feel safe next to the fuel tanks and light up fires next to them, thus, causing the fires. This way, Whorf claims that human beings are only allowed to act and think inside the boundaries and constraints of their own language, or as Whorf (1956) himself puts it:

We dissect nature along lines laid down by our native languages. The categories and types that we isolate from the world of phenomena we do not find there because they stare every observer in the face; on the contrary, the world is presented in a kaleidoscopic flux of impressions which has to be organized by our minds - and this means largely by the linguistic systems in our minds. We cut nature up, organize it into concepts, and ascribe significances as we do, largely because we are part to an agreement to organize it in this way - an agreement that holds throughout our speech community and is codified in the patterns of our language. The agreement is, of course, an implicit and unstated one, but its terms are absolutely obligatory; we cannot talk a tall except by subscribing to the organization and classification of data which the agreement decrees. (p. 213)

Linguistic relativism has been very criticized by many linguists, especially by those who believe in the possibility of an accurate translation of ideas between languages, causing the Sapir-Whorf hypothesis to be 
discredited by many. However, it is important to acknowledge that Sapir and Whorf were very important for Linguistics because it is only because of their studies that, nowadays, there have been studies that question the relationship between language and culture.

One of the authors that have furthered the discussion of the relationship between language and culture is Risager (2006) who uses the term languaculture, coined by Agar (1995) to show how culture and language are linked to each other. According to the author, the term languaculture, then, expresses the power that culture has on language and the influence that language has on culture. In her view, culture and language influence each other mutually to the point that culture is composed of language and language is composed of culture, being culture and language two different things albeit one constitutive of the other. As Agar (1994, p. 28, apud Risager, 2006, p. 112) puts it,

The language in linguaculture is about discourse, not just about words and sentences. And the culture in linguaculture is about meanings that include, but go well beyond, what the dictionary and the grammar has to offer.

Still on languaculture, Risager (2006) claims that culture permeates language in three specific ways. That is, the term languaculture implies the idea that language and culture have three different potentials, so that culture can be expressed in language through: its semantic-pragmatic potential, its poetic potential, and its identity-formation potential.

The first dimension of languaculture is the potential that any language has to be used in everyday pragmatic situations. This sounds quite obvious as it is impossible for people to live and to perform everyday chores without using language, but, at closer inspection, it is in everyday life that culture is manifested and it is in its everyday use that language expresses culture. I will give an example of how much language and culture are tied to everyday situations by mentioning a personal experience. I live in Goiania, a city located in the Mid-West of Brazil, where most people take the bus to go around the city. In most Brazilian cities, however, bus passengers have to pay for their trip to the bus driver so that they can ride the bus around town. In Goiania, however, you have to buy a ticket called sitpasse, without which you cannot take the bus. Most Brazilians I met, when they come to Goiania, find themselves unaware of this situation, ending up not being able to take the bus because they have no idea of what a sitpasse is. As a matter of fact, the word sitpasse is so pragmatically and culturally local that anybody who is not from Goiania might find it hard to grasp what a sitpasse is if they are not told that in Goiania we do not pay our bus drivers directly when we board the bus. Thus sitpasse is not only a piece of language, it is a piece of our culture, too; better yet, it is part of our local languaculture.

Another potential of languacultures is its ability to express art and, along with art, different cultures. As Risager (2005) herself puts it:

The poetic potential is the dimension related to the specific kinds of meaning created in the exploitation of the phonological and syllabic structure of the language in question, its rhymes, its relationships between speech and writing etc. - areas that have for a long time interested literary theorists focusing on literary poetics, style, literariness and the like. (p. 191)

Lastly, the final dimension of languaculture is regarding its identity potential. It is through language and culture that people build and express their identities. As a matter of fact, in many societies, it is through language that certain cultural groups express their political views, their ancestry, their race, their religion, their age, and even their social status. 
Therefore, to learn a foreign language is, whether course books discuss this or not, to study foreign cultural groups and their languacultures. When ESL course books, for example, teach students how to greet each other with "hello, how are you?" instead of "what's up, dude?" course books are teaching a certain culture instead of another, that is, a languaculture instead of many others. Considering the concept of languaculture then, we understand that the teaching of culture is deeply connected to the teaching of language and to teach a certain form of language implies teaching certain forms of culture. Whichever cultures and linguistic varieties that are able to make it to the foreign language classes and course books, though, do so because of rather politically and socially motivated decisions instead of simply linguistically motivated or educational reasons. This is when a critical view of the language classroom comes in handy, it helps us understand the political and social motivations that privilege certain languacultures over others.

\section{Critical Applied Linguistics and Interculturality: Reflections on Languaculture}

So far, we have discussed that language and culture are so closely related to each other that to separate culture from language would be to ignore the very cultural constitution of language and the very linguistic constitution of culture. Needless to say, the language classroom is not only a place to learn the structure of a foreign language, but it is also a place to learn about cultures as well. However, that raises the questions: How do language teachers teach culture, and, better yet, how should they teach it? To answer them, I would like to present a Critical Applied Linguistics view on the teaching of culture.

Pennycook (2001) defines Critical Applied Linguistics as an area of study within Applied Linguistics that seeks to understand how certain issues relate to Traditional Applied Linguistics. In his own words, to do Critical Applied Linguistics is to problematize the status quo, that is, Critical Applied linguistics,

(...) demands a restive problematization of the givens of applied linguistics and presents a way of doing applied linguistics that seeks to connect it to questions of gender, class, sexuality, race, ethnicity, culture, identity, politics, ideology, and discourse. (p. 355)

So, having in mind that Critical Applied Linguistics is a way of connecting questions of "gender, class, sexuality, race, ethnicity, culture, identity, politics, ideology and discourse" to the issues already discussed in Traditional Applied Linguistics, there is a recent trend in Critical Applied Linguistic that is concerned with critical teaching. Based on the works of Paulo Freire (1987), a Brazilian educator whose works talk about the importance of teaching to empower, teachers have realized that the language classroom is more than just a place in which the teacher should "deposit" subjects, thus, treating students as if they were banks of information. Teachers and critical educators see the language classroom as an arena of ideologies and a place to either reinforce the status quo of an unequal society or to empower students so that, through knowledge, they can promote societal justice and change.

Considering this difference between critical and traditional Applied Linguistics and the chasm between traditional teaching and critical teaching, we should also face the way we teach language and culture as if there were two opposite poles: one that seeks to maintain society as it currently is and another that seeks to promote social change (Kubota, 2010). That said, we can divide the teaching of foreign cultures into two distinct categories: (1) a traditional or liberal approach and (2) a critical approach.

In the first approach, in accordance with Kubota (2010), the teacher usually understands culture as a different skill or a set of knowledge to discuss in the class. Culture, in this sense of the word, is only viewed 
according to Bauman's concept of culture as cultural differences between one country and the other, that is, the study of culture is usually restricted to the sharing of some cultural curiosities that the teacher considers typical characteristics of a country. The teacher's job is, then, limited to sharing this "culture" with the students. This first approach neither questions nor focuses on the real problems that these different cultures around the world face, on how different cultures dialog with each other, or on how power plays an important part in how this culture is structured.

An example of a traditional language class that adopts a liberal view on language and culture would be one in which the teacher talks about, for instance, the United States focusing on America's big cities, its holidays and its regions, its people without addressing the social conflicts in these cities, these holidays, and these people. In this view, teaching culture does not encompass addressing the currently problematic issues that permeate American society and the way power plays a role in the keeping of racism, sexism, and homophobia.

Contrary to this approach, Critical Applied Linguistics advocates for a pedagogical practice that aims to problematize the givens of a society, reaching for the marrow of social problems, helping students understand how societies really work and what they can do to help change inequality (Kubota, 2010; Walsh, 2015; Tubino, 2004). This is a critical approach and it is better defined by Walsh $(2006$, p. 13) who believes that a critical intercultural society needs to redefine its pedagogical practices to include in it the questioning of the relations of power that permeate society,

As a political, social, epistemic and ethical project, critical interculturality expresses and demands one pedagogy and one pedagogical practice and proposal that go back to the differences in relational terms, that is, the social historical political relation and power relation, to build and affirm distinct processes, practices and conditions. This way, pedagogy feels closer to the educational system, to the teaching and the transmission of knowledge and as sociopolitical productive and transformative process and practice based on historical and subjective realities and the fights of the people, set in a world ruled by colonial structures. ${ }^{2}$

That said, we should seek "social transformation by seeking social justice and equality among all people rather than merely celebrating differences or just assuming a priori that all people are equal" (Kubota, 2000, p. 30). Since language and culture are so intertwined to each other, it is crucial that the language class be the place where teachers can talk about and problematize cultural issues, such as homophobia, racism, sexism, and all the other relations of power that permeate the foreign societies that use the target language as means of expression. As a matter of fact, an intercultural class should be the one in which even the students' own societies should be problematized, since an intercultural approach presupposes the contact of, at least, two different cultures: the culture of the students and the culture of the other cultural groups that speak the foreign language.

Another author that talks about the development of an intercultural ability from a critical perspective is Kramsch (1993), whose works discusses the importance of helping students create their own cultural third place. Based on Hommi Bhabha's concept of third space, Kramsch claims that it is crucial that students develop a communicative competence that encompasses the ability to critically understand their own home cultures as well as the cultures that express themselves in the foreign language. For that, she says that the

\footnotetext{
${ }^{2}$ I translated the excerpt above from the original text. The original text is as follows: "Como proyeto político, social, epistémico y ético, lainterculturalidad crítica expresa y exija uma pedagogia, y una apuesta y prática pedagógica que retomanla diferencia em términos relacionales, com su vínculo histórico-político-social y de poder, para construir y afirmar procesos, práticas y condiciones distintos. De esta manera, la pedagogia se entende más alládel sistema educativo, de laenseñanza y transmissión de saber, y como proceso y prática sociopolítico productivo y transformativo assentado enlas realidades, subjetividades, historias y luchas de la gente, vividas em um mundo regido por laestructuracioncolonial".
} 
students should not emulate the language and the culture of the Other, but rather, develop their own identity as they study and learn about the foreign language and culture, in other words, they should create a third culture, which she calls a third place.

Kramsch's third place is an interesting concept as it allows us to understand the development of a critical intercultural ability. ${ }^{3}$ According to the author, to understand the notion of third place, one needs to understand that a third place has three main characteristics: (1) it is a popular culture; (2) it is a critical culture; and (3) it is an ecologic culture.

A third place is a popular culture because it is a space constructed by the learners themselves. That is, the teacher, by problematizing the cultures that are expressed in the target language as well as the culture of the students, helps the students understand their own lives as well as the lives of the others. This understanding, however, is not deposited in the learner's head as it would be in traditional education, but rather, it is problematized, inviting students to think and to reconsider their own place in society and in a world full of diverse cultures.

This problematization is a direct result from discussing different relations of power that permeate the societies that speak the target language is also what makes the student's third place critical. The student's third space should never be the one where he feels comfortable to not question his own reality, but rather, his/her third space should be always changing as the student learns more about the foreign languages and cultures. As Gadamer (2000) claims in his famous book Truth and Method, "horizons are always changing for a person who is moving" (p. 304) and so should one's third place change as this one delves into the cultures around him/her.

The last aspect that characterizes this third place is its ecologic view on the world. Students should build their own third places keeping in mind that there are plenty of different cultures in the world, that is, the current world should be seen as an ecology of cultures. In this sense, foreign language learners should be able to develop a critical view that celebrates plurality and that seeks to understand different cultures rather than to judge them or to put them into simplistic boxes of prejudice.

That said, to adopt a critically intercultural stand, teachers should see to it that their students problematize their societies and the societies around them, be it in a macro perspective, when the class discusses other countries, be it in a micro perspective, when the class discusses the many diverse cultures that live side by side with them but that, many times, go unnoticed. This way, the students should be able to, little by little, create their own third places that are popular, critical, and ecologic, always keeping in mind the many cultures that surround them.

\section{Conclusion}

This paper tried to show that the relationship between language and culture has long been studied, with studies going from linguistic relativism to the current studies on languaculture (Risager, 2006). Also, this bibliographical research aimed to discuss the influence of the current discussions inside Critical Applied Linguistics on the teaching and learning of foreign languages (Kubota, 2000) as well as some practical implications of Critical Applied Linguistics to the foreign language classroom as discussed in the theoretical concept of critical third places (Kramsch, 1993).

\footnotetext{
${ }^{3}$ By intercultural ability, I use Corbett's definition: "Intercultural communicative competence includes the ability to understand the language and behavior of the target community, and explain it to members of the 'home community'and vice versa".
} 


\section{References}

Agar, M. (1995). Language shock: Understanding the culture of conversation. New York: William Morrow.

Bauman, Z. (1973). Culture as praxis. London and Boston: Routledge \& Kegan Paul.

Corbett, J. (2003). An intercultural approach to English language teaching. Great Britain: Multilingual Matters Ltd..

Corbett, J. (2006). Intercultural resource pack: Latin American perspectives. Retrieved from https://www.teachingenglish.org.uk/sites/teacheng/files/icrp-july07.pdf

Franklin, P., \& Spencer-Oatey, H. (2009). Intercultural interaction: A multidisciplinary approach to intercultural communication. UK: Palgrave Macmillan.

Freire, P. (1987). Pedagogia do oprimido (Pedagogy of the oppressed) (17th ed.). Rio de Janeiro: Paz e Terra. Retrieved from http://www.mda.gov.br/portal/saf/arquivos/view/ater/livros/Pedagogia_do_Oprimido.pdf

Gadamer, H. G. (2000). Truth and method (2nd revised ed.). New York: Continuum.

Kramsch, C. (1993). Context and culture in language teaching. Oxford: Oxford University Press.

Kramsch, C. (1998). Language and culture. Oxford: Oxford University Press.

Kubota, R. (2010). Critical multicultural education and second/foreign language teaching. In Critical pedagogies and language learning. Cambridge: Cambridge University Press.

Pennycook, A. (1998). English and the discourses of colonialism. London: Routledge.

Pennycook, A. (2001). Critical applied linguistics: A critical introduction. New Jersey: Lawrence Erlbaum Associates, Inc..

Risager, K. (2006). Language and culture: Global flows and local complexity. Great Britain: Multilingual Matters Ltd..

Tubino, F. (2004). Del interculturalismo functional al interculturalismo critico (From functional interculturalism to critical interculturalism). In M. Samaniego and C. G. Garbarini (Comps.), Rostros y fronteras de la identidad (Faces and frontiers of identity) (pp. 151-164). Temuco: Universidad Católica de Temuco.

Valdes, J. M. (Org.). (1986). Culture bound: Bridging the cultural gap in language teaching. New York: Cambridge University Press.

Walsh, C. (2015). Interculturalidad crítica y pedagogia de-colonial: apuestas (des) de el insurgir, re-existir y re-vivir, Quito (Critical interculturality and de-colonial pedagogy: Reflections on revolting, on re-existing and re-living). Retrieved from http://catherine-walsh.blogspot.pt

Whorf, B. L. (1956). Language, thought and reality: Selected readings of Benjamin Lee Whorf. Cambridge, Massachusetts: The MIT Press. 